\title{
Judicial Administration and Enforcement of the Right to Quality Education in South Africa: A Discussion of Selected Case Laws
}

\author{
Isaiah Mmatipe Sefoka \\ Faculty of Management and Law, School of Law, \\ University of Limpopo, Turfloop, \\ South Africa
}

DOI: https://doi.org/10.36941/jesr-2022-0045

\begin{abstract}
This paper examines the judicial intervention in safeguarding the comprehension and the fulfilment of the right to quality education through its pronouncements and judgements. The paper showcase that these judgements and pronouncements have now become essential regulatory tools shaping the administration and enforcement of the right to quality education in South Africa. It emphasizes that the judiciary on its pronouncements showcase the importance of understanding the meaning of the right to education and steadfast the significance of having social services connected to the learning environment for the delivery and realization of quality and sustainable education. It concludes that this right is inalienable and as such, it is incumbent on the government and institutions responsible for the protection of this right to certify that the right is promoted, protected and provided for at all cost. The paper recommends that the judiciary must continuously contribute in ensuring that quality education is promoted and protected by pronouncing judgements that promote quality sustainable education connected with good social services in schools across South Africa.
\end{abstract}

Keywords: Case Law; Enforcement; Judicial Administration; Quality Education; South Africa

\section{Introduction}

The upbringing of the right to quality and sustainable education in a democratic country is an exercise that engrosses all government arms and domains working hand in hand, including the judiciary (Klug, 200o). After the legislature has made the framework available, it is the responsibility of the executive to ensure that the right concerned is enforced and achieved while the judiciary must ensure that the right in question is interpreted appropriately (Ibe, 2007). It is also worth noting that the actual delivery of quality education necessitates a good co-operative governance approach between the provincial and national departments (Sayed, 2004) and or spheres not excluding a strong collaboration with school governing bodies (Skelton, 2013). This paper posits that litigation can be perceived as argumentative; however, it sometimes makes easy to achieve the necessary and improved access to a right inclusive of the right to education (Biegel and Hastings, 1994). On the other hand, legal action may be the only possible way for the marginalised or affected persons to lobby for the redress of their dissatisfactions (Mameli, 2005). Therefore, this paper submits that the right to quality education has been construed and promoted by the judiciary in both the local and the international arena (De La Vega, 1994). 


\title{
2. Conceptual Clarification
}

It is significant to look closely into the meaning of the central concepts adopted in this paper. In doing so, it must be kept in mind that these concepts will, as a result, be subject to different meaning in the context of this paper. The following are some of the relevant and interrelated definitions:

\subsection{Education}

According to Thompson education refers to the action or practise of teaching or being sophisticated; efficient instruction; or improvement of human personality or intellectual powers (Thompson, 1995; 431). Barnhart and Barnhart define education as "the development of knowledge, skill, ability, or character by teaching, training, study or experience" (Barnhart and Barnhart, 1992; 670). On the other hand, Tulloch defines education as an efficient lesson or improvement of human personality and intellectual powers and abilities (Tulloch, 1996). Hornby concurs with the aforementioned definitions and asserts that education is a practice of training, teaching and learning, particularly in educational institution, to advance knowledge and improve abilities (Hornby, 2000;401). For this paper, the word education is used in a broad logic; it consists of the definitions and shades of meaning as provided supra to the inclusion of other meanings of peculiar system of education that promote quality education and skills development such as the process of cultivating quality knowledge and skills to the learners.

\subsection{Basic education}

There is no legislative document in South African jurisprudence that defines the phrase basic education and the judiciary has neither defined it (Simbo, 2012). For this study and for a vibrant implication of the phrase "basic education" this paper asserts that the Jomtien World Declaration on Education for All defined the phrase to mean elementary learning necessities (World Declaration on Education, 1990). In defining the phrase, the World Declaration stated that the attainment of elementary education is identical to the attainment of elementary learning necessities. This implies that the phrase "basic education" denotes to rudimentary educational necessities. In explaining the elementary learning necessities, the World Declaration states that:

\begin{abstract}
"These needs comprise both essential learning tools (such as literacy, oral expression, numeracy, and problem-solving) and the basic learning content (such as knowledge, skills, values, and attitudes) required by human beings to be able to survive, to develop their full capacities, to live and work in dignity, to participate fully in the development, to improve the quality of their lives, to make informed decisions, and to continue learning. The scope of basic learning needs and how they should be met varies with individual countries and cultures, and inevitably, changes with the passage of time" (World Declaration on Education, 1990; Art 1 (1)).
\end{abstract}

For this paper, the phrase "basic education" means the attainment of elementary educational necessities which composes of indispensable learning resources such as school furniture and books which promote the rudimentary learning content. This explanation means that the phrase is qualityoriented.

\subsection{Higher education}

Following the definition of the World Declaration on Higher Education adopted by the World Conference on Higher Education, higher education refers to:

"all types of studies, training or training for research at the post-secondary level, provided by universities or other educational establishments that are approved as institutions of higher education by the 
competent state authorities" (World Declaration on Higher Education,1998). According to this declaration, this includes "all the activities a given country deems to be higher education - not only those that take place within ordinary universities and graduate schools, but shorter-term education and training courses (polytechnics, junior colleges, and various forms of technical speciality schools) that are 2-3 years in length, and even correspondence courses that make use of information technology and are targeted at a broad population of students" (World Declaration on Higher Education,1998).

\title{
2.4 Quality education
}

According to United Nations International Children's Emergency Fund (UNICEF) 1946, quality education embraces:

\begin{abstract}
"Learners who are healthy, well-nourished and ready to participate and learn, and which also receive learning support from their respective families and communities; Environments that are healthy, safe, protective and gender-sensitive, and provide good infrastructure and adequate socio-economic goods and services for pro-active learning; Content that is reflected in relevant curricula and materials for the acquisition of basic skills; A process through which educators use learner-centered pedagogies to facilitate teaching and learning which reflect the necessary materials and programmes for the attainment of quality basic skills; Educational results incorporating relevant skills and knowledge required for positive participation in society" (UNICEF, 2000:3).
\end{abstract}

\section{Statement of the Problem}

Notwithstanding the fact that litigation can be perceived as combative, it can also assist in ensuring that aggrieved persons achieve suitable and improved access and realization of the rights such as the right to education as preserved in the Bill of Rights. Despite how judiciary is viewed, the reality on the ground has proved that any attempt to transgress the right in the Bill of Rights is usually resisted by the judiciary through its pronouncements. This is because of the significant role played by these rights in the lives of the citizens and the society in general such as the right to education. Hence, the judiciary, as part of its judicial activisms interprets the laws in such a way that it will lead to the realization and enforcement of the rights such as the right to education. This study emphasizes that the prominence of the administration and enforcement of this right has been deliberated and interpreted by the judiciary in the local and the international arena.

\section{Research Methodology}

The approach employed in this paper is a qualitative approach generally acceptable in legal research. This study utilizes a desktop analysis of secondary materials more in particular library resources and relies heavily on scholarly legal literature which includes textbooks, articles, case law, legislation, policies and regulations promoting the provision of education and primary information from reports of relevant departments and or ministries of education dealing with the right to education in South Africa. Other instruments talking to the provision of resources connected to the right to education are also examined.

\section{Purpose of the study}

This paper seeks to showcase how the judiciary is playing an active role and has since become an essential regulatory tool shaping and compelling the administration and execution of the right to quality tutelage in South Africa. The paper provides insights as to how the government can ensure that there is effective administration and enforcement of quality and sustainable education. 


\section{Significance of the Study}

This study will make the following contributions to the body of knowledge thus:

It will establish the development of legal reforms that will improve the provision of education including the administration and enforcement of the laws promoting quality education. It will assist in improving and facilitating the provision and realization of the right to quality education in South Africa. It will also be beneficial to the presiding officers to pronounce good judgements promoting the realization of quality education.

\section{The Judicial Nature and Meaning of the Right to Education}

The case of governing body of Juma Musjid Primary School E Others v Essay N.O. 2011 (7) BCLR 651 (CC) emphasized the "nature" and what is meant by "immediately realizable" of the right to elementary education (Skelton, 2012). This case involved several learners who were enrolled in a public school located on someone's property. The owner of the said private property successfully approached the court for an eviction order and as such evicted the leaners from the school. As a result of the dissatisfaction of the High Court decision, the state together with the school governing body appealed the decision and required remedy in the Constitutional Court. It was however the apprehension of the court that the leaners should be left with an alternate placement into another school (Juma Musjid v Essay, 2011: par 74\& 78).

In its ruling, the Constitutional Court emphasized the importance of understanding the nature of the right to elementary education as entrenched in section 29 (1) (a). The Court emphasized that the right differs from other socio-economic rights which are not instantly achievable and as such, there is no core constraint which requires that the right be gradually realized. It held that:

"the right to basic education is distinct from other rights merely because it may only be limited in terms of a law of general application unlike the right to further education which the state is only obliged to make it progressively available and accessible" (Juma Musjid v Essay, 2011 par 37).

In emphasizing the prominence of the nature and meaning of this right the Court also referred to section 28(2) of the Constitution which stipulates that:

"a child's best interests are of paramount importance in every matter concerning the child".

The judiciary through its pronouncements did not only emphasised the nature and meaning of the right to education but it also ventilated on the importance of having good infrastructural amenities and ample socio-economic resources for the realisation of quality education. These were emphasised in the case of Section $27 v$ Minister of Education where an application was presented in Court on an urgent basis, in a quest for an order declaring the conduct of the Department of Basic Education to fail to make delivery of textbook to schools cutting across Limpopo Province to be in defilement of the learners' rights to education. The applicants sought a relief compelling the department to deliver the required books to the schools across the province. The court observed that:

"education is critical in both freeing and unlocking the potential of each person and it also found that textbooks are an essential component of quality teaching and learning" (Section 27 case, par 22).

The Court ruled that the department's failure to deliver books in schools creates an encroachment of the learners' right to elementary education (Section 27 case, par 32). It also pointed out that if a right is violated it should be followed by an effective and meaningful remedy. If that does not happen it means that the rights are not protected and the Court must act according to spirit and purport of the Constitution and to ensure that if a right is violated, appropriate remedies are implemented to cure the situation. Moreover, the Court said that: 
"there is no doubt that an order only for delivery of textbooks will not address the consequences and effects of the failure of delivery for the first half of the year". The whole situation boils down to require strong intervention by the Court to address the loopholes in learning and the quality in learning and teaching. (Section $27 v$ Minister of Education 20132 SA 40 (GNP) para 36).

In Madzodzo and Others $v$ Minister of Basic Education and Others the Eastern Cape High Court handed down a ruling wherein a relief was sought against the National and Provincial Education Departments to force them to distribute appropriate school furniture to schools in the province. The Departments of Education contended that:

"the allocation of resources, procurement and delivery of furniture could only happen after an independent audit of furniture shortages across all schools in the Eastern Cape was completed later that month".

The Court overruled this department's argument and confirmed that:

"school furniture is an integral component of the right to basic education as enshrined in section $29(1)(a)$ of the Constitution, and that the state is obliged to take all reasonable measures to realise the right with immediate effect" (Madzodzo case, 2014: par 17).

The Court held that:

"the Departments of Education breached the learners' constitutional right as provided for in section 29 of the Constitution by failing to provide adequate age-and-grade-appropriate furniture that would enable each child to have his or her own reading and writing space and the persistent failure by the department to deliver such appropriate furniture to schools constituted an ongoing violation of the right to basic education" (Jamieson \& Stein, 2014:15).

The other case that dealt with the judicial administration and enforcement of having good infrastructural amenities is the case of Komape and Others $v$ Minister of Basic Education. It is indispensable to highlight that in discussing this case, deliberations will only be limited to what is relevant to this paper which fact promote the administration and enforcement by the courts. This case concerns Michael Komape, a pupil who attended grade R at a rural school near Seshego in the Limpopo Province. He met his untimely death when he fell into a pit latrine located on school premises which led to his parents' dreams and expectations to a shattering and tragic end. The plaintiffs (members of the Komape family) sought relief following his death. Amongst the relief sought, they also claimed for the punitive damages to penalize the respondents and compensation for the loss suffered following the alleged rupture of the defendants' statutory rights and obligations (Komape and Others v Minister of Basic Education Par 7 and 9).

The court indicated that the objective of a claim for damages is not aimed at enriching the applicant who would have suffered harm, but it is aimed at compensating them for the damage incurred (Komape Par 67). In this regard, the court described the compensation claim by the plaintiffs as retributive damages. It further pointed that in situations where courts are confronted with such claims, they must rule looking into the fairness and the equitable of the award. Muller J opined that in his view, a suitable relief is an order aimed to enforce, promote, protect and to prevent future infringement of the rights enclosed in the Bill of Rights (Komape par 67).

The court held that it is not convinced that retributive damages would be a proper relief in this regard and if the plaintiffs are successful in this claim, they will therefore be over enriched and as such, that would not promote the public interest (Komape par 68). The court held that a structural interdict is a proper, fair and reasonable relief which will maintain the constitutional provisions effectively. The court further held that the best interest of every learner attending rural schools with pit sanitary facilities across the province must take preference (Komape par 70). In the court's opinion, this is the only effective way to ensure that government take initiatives to provide basic 
sanitary facilities where there is none and to improve those facilities where they are lacking in those schools. The court acknowledged with no doubt that to achieve this will need a lot of effort on the part of the state, however, that cannot prevent it from directing the state to meet and fulfil its constitutional commitments (Komape par 70).

The court ordered both the first and the second defendants to provide and erect at each rural school fortified with pit sanitary facilities across the Province an adequate quantity of proper and dignified latrines for each school for the usage of all learners which are easily accessible, secured and harmless and which afford confidentiality and promote health and hygiene (Komape par 72). Despite the fact that the court was mindful that this order will place an extra liability on the state's financial means, it required the first and second defendants to put before it relevant information regarding the exact time they will take and the necessary program they will develop to achieve this goal. This, said the court, will enable it to perform a supervisory role in executing the order to justify the constitutional right of the learners attending schools with poor and degrading sanitary facilities in rural Limpopo (Komape par 70).

In its administration process, the court also deliberated on the issue of access to education. This was stressed in the case of Welkom High School v Head, Department of Education, Free State Province. This case involves two cases which were logged independently to the Bloemfontein High Court and were later combined owing to their resemblances. In these cases, the girls involved were pregnant and as such, they were told not to come to school because of their pregnancies. The decision to negate the two girls access to education was as a result of the "pregnant learner policy" which was adopted by the governing bodies of each school. These policies were founded on a National Department of Basic Education policy of 2007 referred to as "measures for the prevention and management of learner pregnancies" (National Department of Basic Education policy, 2007; Measure 22).

In its decision, the court remarked that there are two groups of children adversely impacted by these resolutions, namely the teenage mothers and their babies. The court further held that:

"maybe the greatest gift that can be given to the two babies of the two teenage mothers is to ensure that their mothers continue to learn so that they can become better parents in the near future (Welkom High School v Head, Department of Education par 8o)".

\section{Conclusion and Acclamations}

The judiciary is proactively contributing towards the enforcement and the progressive realization of quality education by steadily restating in their rulings and pronouncements that this fundamental right is an enabling right that empowers individuals to appreciate their potential and advance their well-being. Moreover, reality has proved that these judgements and pronouncements have now become essential regulatory tools shaping the administration and execution of this right. These pronouncements showcase the importance of interpreting the meaning of the right to education and steadfast the significance of having quality education as a country. It is for this reason that this paper concludes that the right to education is inalienable and as such, it is incumbent on the government, the judiciary and other institutions responsible for safeguarding the right and to guarantee that it is promoted, protected and provided for at all cost. The paper recommends that the judiciary must continuously contribute to ensuring that quality education is promoted and protected at all costs by pronouncing judgements that promote quality sustainable education across South Africa. The judiciary must as well ensure that precedents promoting the administration and enforcement of this right are followed appropriately.

\section{Funding}

This work was supported by the National Institute for the Humanities and Social Sciences and South African Humanities Deans Association, grant number SDS16/1187. 


\section{References}

Barnhart, C. L. \& Barnhart, R.K.(1992) The World Book Dictionary. Volume One, A-K. Chicago: World Book, Inc. Biegel, S., \& Hastings, L. J. (1994) School Choice Policy and Title VI: Maximizing Equal Access for K-12 Students in a Substantially Deregulated Education Environment, Hastings Law Journal, 6:1533-1541. (1994-1995).

De la Vega, C. (1994) "The Right to Equal Education: Merely a Guiding Principle or Customary International Legal Right? 11 Harvard BlackLetter Law Journal 37.

Hodson, D. (2003) Time for action: Science education for an alternative future. International Journal of Science Education, pp. 645-670.

Hornby, A. S., (2000) Oxford Advanced Learner=s Dictionary of Current English. Oxford: Oxford University Press.

Ibe, S. (2007) Beyond justiciability: Realising the promise of socio-economic rights in Nigeria. African Human Rights Law Journal, 7(1):225-248.

Jamieson, L., Stein, N., \& Waterhouse, S. (2014) South African Child Gauge, part one: Children and law reform, 86116.

Juma Musjid Primary School \& Others v Essay N.O. 2011 (7) BCLR 651 (CC).

Klug, H. (2000) Constituting democracy: Law, globalism and South Africa's political reconstruction. Fromhttps://scholar.google.co.za/scholar?hl=en\&q=judiciary\&btnG=\&as_sdt=1\%2C5\&as_sdtp=.

Komape and Others v Minister of Basic Education (1416/2015) [2018] ZALMPPHC.

Madzodzo and Others v Minister of Basic Education and Others 2014 (3) SA 441 (ECM).

Mameli, A. (2005) 'Judicial review, social antagonism and the use of litigation as a tool for combating poverty' in Williams et al (eds) Law and poverty (London, Zed Books).

Mubangizi, J. C. (2006) The Constitutional Protection of Socio-Economic Rights in Selected African Countries: A Comparative Evaluation. http://booksandjournals.brillonline.com/content/journals/10.1163/221097312x1339 74997363 45. (Retrieved 16 July, 2014, revisited 15 August 2019).

Sayed, Y. (2004) The case of teacher education in post-apartheid South Africa: politics andpriorities.Fromhttp://scholar.google.co.za/scholar_17m2sjVrf8NsegmAGziYX4Cg\&scisig=AAGBfmırymr Mh2kHqoY9AUwGKuF_HfcGjg\&no ssl=1\&ws=1366x561. Retrieved 16 June, 2014.

Section $27 \mathrm{v}$ Minister of Education $20132 \mathrm{SA} 40$ (GNP).

Simbo, C. (2012) Defining the term basic education in the South African Constitution: An international law approach, Law Democracy \& Development Vol 162012 African Journals Online (AJOL) page 163. Also available at http://dx.doi.org/10.4314/ldd.v16i1.9 retrieved 28.04.2019.

Skelton, A. (2012) How far will the courts go in ensuring the right to a basic education? Southern African Public Law, 22(7):392-408.

Skelton, A. (2013) The role of the courts in ensuring the right to basic education in a democratic South Africa: a critical evaluation of recent education case law, De Jure, 46:1-6.

Thompson, D. (1995) The Concise Oxford Dictionary of Current English. Ninth edition. Oxford: Claredon.

Tulloch, S. (Ed.) (1996) Reader s Digest. Oxford Complete Word finder. Oxford: Clarendon Press.

UNICEF -Defining Quality in Education, A paper presented by UNICEF at the meeting of the International Working Group on Education Florence, Italy June 2000, pp 1-43.

Welkom High School v Head, Department of Education, Free State Province 20114 SA 531 (FB).

World Declaration on Education for All and Framework for Action to Meet Basic Learning Needs. Adopted by the World Conference on Education for All Meeting Basic Learning Needs Jomtien, Thailand (1990).

World Declaration on Higher Education adopted by the World Conference on Higher Education in 1998. 